\title{
Minha Primeira Turma
}

\author{
Paulo José da Costa Jr. \\ Professor Titular de Direito Penal na \\ Faculdade de Direito da Universidade \\ de São Paulo. Livre docente de Direito \\ Penal na Faculdade de Direito da Uni- \\ versidade de Roma.
}

No dia do professor, à saída das aulas, vieram comunicar-me: "o senhor foi eleito paraninfo". Para quem nunca foi candidato a coisa alguma, ser escolhido assim, pelos corações espontâneos dos discípulos, era a dádiva mais grandiosa que se poderia receber, naquele dia.

A notícia inundou-me d'alegria a alma. Uma sensação de plenitude aqueceu-me o corpo, na noite fria. Era o calor da amizade, da mocidade que não mente. Que não engana. Que escolhe com a autenticidade dos que não tem interesse. E acabam por optar por aquêle que não é mais professor. Que não pode em nada retribuir. Nem com nota. Apenas com o afeto forte do latino afetivo que tem a verdadeira religião da amizade. Leal, desprendida, fervorosa, desinteressada.

A alegria foi ainda maior porque neste ano de Nosso Senhor Jesus Cristo de 1971 faz exatamente meio século que meu pai saiu destas Arcadas, enquanto que minha mãe, também há cinqüenta anos, formou-se na Escola de Farmácia da Universidade de São Paulo. E enquanto êles dois celebram, logo mais, felizes e fortes, com as bênçãos de Deus, suas bodas de ouro, comemoramos nós, nesta noite, a vossa colação de grau.

*. Discurso de paraninfo à turma “Castro Alves” de 1971. 
Eleito paraninfo, radiante, relatei o fato a professôres universitários italianos, amigos meus. Entre perplexos e sorridentes, interpelaram-me:

"Hai detto paraninfo?"

Disse-lhes que sim. A perplexidade virou espanto e seguiu-se de nova pergunta:

"Mas paraninfo se elege no Brasil?"

Percebi que algo de errado estava se passando. Expliquei-lhes então, com minúcias, o que era paraninfo em nossa terra. Fiquei ai sabendo do seu outro significado, desde a linguagem setecentista italiana: alcoviteiro.

Na cibernética dos tempos atuais, a máquina amesquinha o homem. Substituindo-o, com vantagem. Eliminando-o. Aviltando, arrazando, invadindo. $\mathrm{O}$ micro-homem vencido pela super-máquina. Pelo computador. Pela eletrônica. Que raciocina melhor. Que produz mais. Sem falhas, nem erros. A civilização da técnica, identificando o homem com sua função social, transformando-o em insignificante peça da complexa engrenagem industrial, nele inculcando sentimentos de desvalorização. $O$ homem se sente esmagado pelo anonimato, pela diluição de sua individualidade nas grandes concentrações urbanas da era industrial-tecnológica De tal sorte, que a exposição de sua vida à curiosidade e contrôle alheio resulta, paradoxalmente, na superação de sua mediocridade.

Numa época que aplaude o exibicionismo e que encoraja a experiência comunal, o homem habitua-se a ser espoliado em sua privaticidade. Compraz-se até em fornecer informações pessoais. Troca mesmo a análise individual, no retiro do consultório, pela dramatização da psicanálise de grupo, que elimina de vez o recato e desnuda o próprio subconsciente.

De outra parte, o liberalismo vai cedendo lugar à estatização. O Estado pode mais. Hipertrofia-se. Comanda mais, proibe mais. $\mathrm{E}$ o individuo se vê sufocado, eliminado. 
Leis amontoam-se. Multiplicam-se. Conflitam. Geram incerteza. Incerteza do Direito. Sensação de insegurança. Angústia.

$O$ indivíduo, para salvaguardar a individualidade, tenta debalde reagir. Protesta. Para não se transformar num robô. Para não se entregar por completo, tragado pela máquina e pelo Estado, lança um brado surdo e vão, onde só contesta.

Descoroçoado e derrotado, volta-se à divindade. "Nos lábios dos horizontes há um riso de luz... é Deus." (CAstro Alves). Ou então pede que a divindade dêle se aperceba. Que o socorra, porque só, desprotegido, suprimido. "Jesus Cristo, eu estou aqui."

Minha primeira turma. Minha primeira e querida turma. Sois minha, tanto quanto vossa. Permiti que assim o seja. Que eu faça parte dela. Vivendo a vossa emoção dêste momento solene. Compartilhando da mesma alegria contagiante de vossos pais, cônjuges, filhos e irmãos. A quem deveis o estimulo encorajador, mesmo que desaparecidos. $\mathrm{E}$ a quem rendo, porisso, a homenagem profunda de meu coração que se ajoelha, comovido e agradecido por todos vós.

Logo mais ireis deixar os muros de granito do velho casarão, para iniciardes o vosso combate. Já findastes o curso. Não há mais provas a prestar nem aulas a serem ouvidas. Resta-vos tão somente a palavra final. A palavra de despedida. Dos derradeiros conselhos. Que terei eu o privilégio de dar.

Irá falar-vos não o professor, mas o advogado, o colega. De igual para igual. Com carinho, com franqueza, com objetivismo.

Dentro em breve, ireis defrontar-vos com a prática forense. Com a concorrência de vinte mil colegas, só neste Estado, número superior ao de advogados da Alemanha Ocidental e da Inglaterra, mais que o dôbro dos advogados de França. 
Caberia, aqui, a advertência de Piero Calamandrei: "Muitos advogados!" Sim, muitos advogados mal preparados.

Estais em melhores condições para enfrentar a luta. Com melhor preparo: o preparo das Arcadas, que ainda é o melhor dêste Brasil.

Logo mais ireis penetrar, já formados, no Palácio de Justiça. Não vos decepcioneis se, como em França, muitas vêzes não encontrardes "ni palais... ni justice". Ides defrontar-vos com dificuldades inúmeras e espinhosas. Difícil será a primeira causa. Difícil a primeira derrota, sobretudo comunicá-la ao cliente confiante. Difícil a primeira vitória, para não atrair o despeito do vencido. Dilícil a primeira ingratidão do cliente que se defende com tenacidade e denôdo. Difícil sorver o fel da injustiça, quando se sabe da inocência que não se conseguiu provar.

Quais os dotes que deve o advogado reunir?

Antes de mais nada, a probidade. Não a honestidade vulgar, ostentada e alardeada por tantos, mas a honradez que promana do interior, como imperativo categórico de consciência, como abnegação desinteressada da causa. Como encargo, como dever e não como qualidade. Assim, não estimular a propositura de causas perdidas: dissuadir o cliente ou alertá-lo contra os riscos do litígio. Não falsear a verdade: se prejudicial ao cliente, quando muito, calar a verdade. Não oferecer os seus préstimos profissionais: aguardar, com resignação e paciência, que o cliente venha até êles. Não delongar inutilmente os processos, repetindo os "moratores" da velha Roma. Não granjear fama pelo cortêjo e pelo subôrno da imprensa subalterna.

Até aqui, a probidade. Imprescindível, ainda, o desvêlo. Nele se compreende a diligência, o estudo, a tenacidade. Não basta ao advogado diligente a dedicação à causa. Faz-se necessário que não contrate trabalho superior às suas fôrças, que venha obrigá-lo a descurar de causas menos importantes. Para um advogado tôdas as causas deverão situar-se 
num mesmo plano. A tôdas deverá consagrar igual zêlo e paixão. Porque tôdas encerram um bem ofendido, um direito a ser tutelado, uma injustiça a ser reparada.

$O$ estudo do processo deve ser feito, inicialmente, com penetração e argúcia. Depois, com frieza, lógica e equilíbrio. Por derradeiro, com arrebatamento e ardor. Somente após conhecer-lhe os meandros, a alma do protagonista, as questões intrincadas de Direito, uma vez dominados os pontos fundamentais e dissipadas as dúvidas é que o advogado, como senhor da verdade conquistada, estará em condições de sustentá-la diante dos julgadores.

Outros dons relevantes restariam infecundos se divorciados da pertinácia, se ausentes do "labor improbus", da "constans et perpetua voluntas".

Além da probidade e dedicação, também clareza, síntese, capacidade de expressão, robustez de argumentação, preparação técnica, inteligência viva e ágil, poder de improvisação, sensibilidade jurídica, equilíbrio, intuição, reputação, prestígio, memória e bons auxiliares.

Reunidas tôdas as qualidades que veem de ser apontadas, somadas à experiência do velho o ardor do jovem, estaria o profissional inexoravelmente fadado a conseguir fama e glória?

Nem sempre. Quantas mediocridades consagradas pela boa fortuna, pela promoção publicitária. Quantos espíritos mesquinhos pontificando graças ao casamento, ì parentela, ao dinheiro, à simpatia ou amizade. Além de tudo, quantos fatores a impedir o estudo, a turbar a confiança, a estimular a improbidade: multiplicação infindável da legislação e falta de tempo para o estudo; progresso material, ambição de conforto, encarecimento do custo de vida; cartórios abarrotados, funcionários relapsos, Justiça morosa.

Tempos já houve em que se sentia o jurista ninguém diante dos'técnicos e dos cientistas. Hoje, imudou. Nunca o mundo necessitou tanto da humanização da tecnologia como hoje. Nunca a figura do jurista se fêz tão necessária e presente. 
Sois o guardião dos segredos invioláveis, o intérprete das angústias, o defensor das opressões. Sois vós que, sem armas, afugentais a violência. Com a vossa palavra, comoveis os indiferentes e confortais os necessitados. Consolais a dor que soluça, enxugais a lágrima que escorre, auscultais o coração que palpita. Do vosso desempenho dependem o potentado na adversidade e o oprimido em meio à tirania, o pobre e o rico, o poderoso e o fraco, o pária e o eleito.

Turma de Castro Alves, turma da liberdade: o embate vos conclama, lá fora. Desembainhai as vossas penas. Aprestai-vos. Os clarins e as trombetas anunciam a luta pelo Direito e pela Justiça.

Já está desfraldado o Pavilhão da Pátria, o "auriverde pendão da minha Terra que a brisa do Brasil beija e balança". Empunhai o "estandarte que a luz do sol encerra": o estandarte do liberalismo que personificais. A vossa responsabilidade é bem maior. Levais o nome daquele que devotou toda uma vida à causa da liberdade.

Confio em vós. No vosso desprendimento, no vosso destemor, na vossa combatividade. Não havereis de curvar-vos às ameaças, ou às opressões injustas. Havereis de pugnar, com lealdade, coragem e elegância, sem o servilismo subserviente nem a petulância arrogante, falando a linguagem veemente da convicção, mas sem descer ao insulto.

Se da vossa atuação depender a liberdade, a honra, o patrimônio de um cidadão lesado, tendes o direito e o dever de agir com inteira independência. Não havereis de deter-vos diante dos temores da desaprovação, nem recuardes em face dos riscos da impopularidade.

Creio em vós, ó mocidade acadêmica das Arcadas, ó turra radiosa de Castro Alves! Creio em vós, forjados nesta Academia-milagre de amor que tem desfiado, franciscanamente, de geração em geração, durante os anos dos séculos, as contas rubras do rosário da Justiça, da Liberdade e do Direito. 